\title{
Geographical distribution of phenotypes regulating pigmentation in the spider Enoplognatha ovata (Clerck) (Araneae: Theridiidae)
}

\author{
G. S. Oxford
}

Department of Biology, University of York, York YO1 5DD, U.K.

\begin{abstract}
The time when red pigment is deposited in the ovata and redimita morphs of Enoplognatha ovata is determined by a closely linked regulatory locus. In Nidderdale, Yorkshire, red pigment in the ovata morph is deposited early in development but the redimita pattern can develop either early or late. Phenotype frequencies at the regulatory locus define two main areas; one of which has a high and the other a very low frequency of the regulatory phenotype causing early production of red pigment. Phenotype frequencies at the regulatory locus and at the structural locus upon which it acts are not correlated. Bottlenecks in populations in the past might be responsible for allelic distributions at both loci, although selection cannot be excluded.
\end{abstract}

\section{INTRODUCTION}

Variation in regulatory genes in natural populations has received little attention until recently, although the evolutionary importance of changes in gene regulation has long been appreciated in, for example, the evolution of several major groups through paedomorphosis (Gould, 1977). Experiments and observations on regulatory-gene variation (Wilson, 1976; McDonald et al., 1977; McDonald, 1983) together with theoretical analyses (Hedrick and McDonald, 1980) have not yet clarified the relevance, if any, of regulatory-gene variation in extant populations to major phylogenetic events.

Variation at regulatory gene loci can be recognised in three main (but non-exclusive) ways. Regulatory elements may be identified by differences in level of enzyme activity when a structural locus is placed in different genetic backgrounds (e.g. Barnes and Birley, 1978; Tejima and Ohba, 1981; Wilson and McDonald, 1981; LaurieAhlberg et al., 1982; Maroni and Laurie-Ahlberg, 1983). Alternatively, different regulatory elements might shift the tissue-specific expression of enzyme activity, or could affect the time when enzymes are produced during development (e.g., Schwartz,
1962; Dickinson, 1975; 1981; Abraham and Doane, 1978; Paigen, 1979; Hoorn and Scharloo, 1981; Allendorf et al., 1982).

Although these studies provide good evidence for the widespread occurrence of regulatory-gene variation little is known of the geographical distribution of different regulatory alleles although such information might suggest selective factors responsible for maintaining them. The little work that has been published concerns shifts in tissue-specific enzyme activity (Powell, 1979) or changes in the timing of gene expression during development (Heller and Volokita, 1981).

Another example of variation in the timing of gene expression is found in the spider Enoplognatha ovata (Oxford, 1983). E. ovata exhibits three main colour morphs. In lineata, the opisthosoma is plain yellow. Redimita bears two dorso-lateral carmine stripes across the yellow opisthosoma while in ovata the whole of the dorsal surface of the opisthosoma is carmine (see Plate 1a, b, c in Oxford, 1983). These morphs are determined by three alleles at an autosomal locus with a dominance hierarchy such that the ovata pattern is top dominant and lineata bottom recessive. This hierarchy is always shown by mature females but does not hold in some males (see below). 


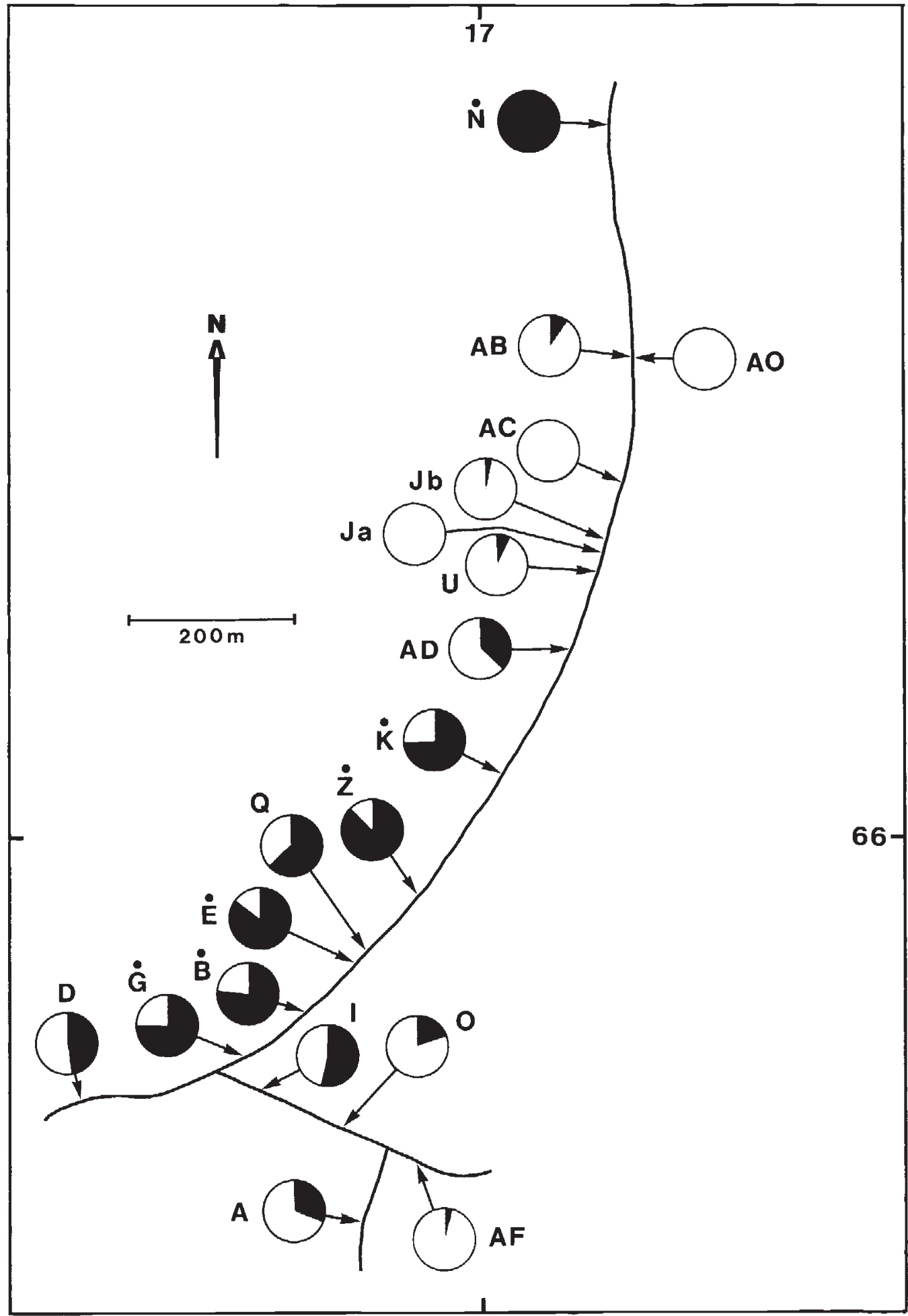

Figure 1 Map of the Nidderdale study area showing for each site its position relative to roads or tracks (black lines) and the proportion of early developing redimita in total redimita (shaded segment). In sites marked with a dot the null hypothesis, that the frequency of late developing redimita is zero, was not rejected. Marginal numbers indicate Ordnance Survey grid lines. The full map reference for the south western corner is SE164654. 
All young spiders have yellow opisthosomas. Red pigment may appear either in the third or fourth instars or at maturity. For patterns which develop early, the frequencies of redimita and ovata are independent of sex. When pigment is laid down at maturity however, red-patterned morphs are confined to females; males remain yellow (but can be shown to be carrying redpigment producing alleles). Late developing ovata and redimita morphs are therefore sex-limited to females. I suggested that this dimorphism in the timing of pigment deposition is controlled by two alleles at a regulatory locus tightly linked to the structural locus. Regulatory alleles are cis-acting on their respective structural alleles (Oxford, 1983).

Here I describe the distribution of these two regulatory phenotypes and the three visible morphs in a small area of Nidderdale, Yorkshire.

\section{METHODS}

All the Enoplognatha sites reported here lie within the area of Nidderdale described by Oxford (1976). The relative locations of the sites are shown in fig. 1 and details of some of their physical attributes and major vegetation components are given in table 1. Sites consist of a patch of broad-leaved vegetation (often bramble, Rubus fruticosus $\mathrm{L}$. sensu lato or raspberry, Rubus idaeus L.), isolated to a greater or lesser extent from other patches by a stretch of grass or other herbage unsuitable for the construction of nursery retreats by females. Spiders are common within a site and occur only sporadically elsewhere. In two cases $(\mathrm{Ja} / \mathrm{Jb}$ and $\mathrm{E} / \mathrm{Q})$ sites are arbitrary divisions of a continuous stretch of vegetation. $\mathrm{Ja}$ and $\mathrm{Jb}$ abut one another whereas $\mathrm{E}$ and $\mathrm{Q}$, although in the same bramble clump, are separated by a third site (R). All sites border roads or tracks and are backed by dry-stone walls, and each is identified by markers at either end. This is the only habitat in the study area suitable for $E$. ovata since beyond the walls lie pasture or moorland.

Sites were sampled by intensive searching at least twice per season, usually in mid to late June and again in late July to mid August. Each spider was scored for sex, colour pattern phenotype and stage of development (mature/immature). Mature males were recognised by their fully developed palps and mature females by their obvious epigynes. Except on three occasions individuals were released into the ground vegetation after scoring.

On the final sampling occasion in each season only mature females were present and they were found within rolled leaves, often guarding an egg cocoon. These were scored in situ.

Table 1 Some physical and vegetational attributes of the Nidderdale sampling sites

\begin{tabular}{|c|c|c|c|}
\hline Site & Altitude (m) & Aspect & Vegetation \\
\hline A & 262 & E.S.E. & $\begin{array}{l}\text { Bramble (Rubus fruticosus L. sensu lato) in long grass. Some bracken (Pteridium } \\
\text { aquilinum (L.) Kuhn) at north end }\end{array}$ \\
\hline B & 275 & S.S.E. & $\begin{array}{l}\text { Bramble with interspersed meadow vetchling (Lathymus pratensis L.) bordered } \\
\text { by long grass }\end{array}$ \\
\hline $\mathrm{D}$ & 239 & S.S.E. & Open bramble bordered by long grass \\
\hline $\mathrm{E}$ & 278 & S.E. & Bramble bordered by long grass \\
\hline $\bar{G}$ & 267 & S.S.E. & Open bramble interspersed with long grass \\
\hline I & 268 & S.S.W. & Bramble with willowherb (Chamaenerion angustifolium (L.) Scop.) in long grass \\
\hline $\mathrm{Ja}$ & 313 & E.S.E. & $\begin{array}{l}\text { Hedge woundwort (Stachys sylvatica L.) and scattered raspberry (Rubus idaeus } \\
\text { L.) in long grass }\end{array}$ \\
\hline $\mathrm{Jb}$ & 313 & E.S.E. & Raspberry and scattered hedge woundwort in long grass \\
\hline K & 299 & S.E. & Dense willowherb bordered by long grass \\
\hline $\mathbf{N}$ & 328 & E.N.E. & $\begin{array}{l}\text { Heterogeneous site with bramble, raspberry, bracken and mint (Mentha } \\
\text { rotundafolia (L.) Huds.) in long grass }\end{array}$ \\
\hline $\mathrm{O}$ & 270 & S.S.W. & Open bramble and nettle (Urtica dioica L.) in long grass \\
\hline Q & 281 & S.E. & Bramble bordered by long grass \\
\hline U & 313 & E.S.E. & Bramble bordered by long grass \\
\hline $\mathbf{Z}$ & 290 & S.E. & $\begin{array}{l}\text { Heterogeneous site with rose (Rosa canina agg.), dandelion (Taraxicum spp.) } \\
\text { and creeping buttercup (Ranunculus repens L.) }\end{array}$ \\
\hline $\mathrm{AB}$ & 318 & E. & Scattered nettles in long grass \\
\hline $\mathrm{AC}$ & 316 & E.S.E. & Scattered hedge woundwort in long grass \\
\hline $\mathrm{AD}$ & 309 & E.S.E. & Scattered hedge woundwort in long grass \\
\hline AF & 270 & N.N.E. & Bramble and scattered hogweed (Heracleum sphondylium L.) in long grass \\
\hline $\mathrm{AO}$ & 318 & W. & Scattered raspberry in long grass \\
\hline
\end{tabular}


RESULTS

In Nidderdale ovata always develops early, whereas redimita may develop either early or late. Ovata individuals, therefore, do not provide useful information on regulatory gene variation and are ignored in most calculations. All redimita males have an early developing pattern (see introduction). Redimita in an immature female must be early developing whereas in mature females this morph may have appeared either early or late. Thus the number of redimita in males plus immature females can be used to estimate the frequency of early developing patterns, while those in mature females will yield an estimate of the total frequency of redimita (both early and late developing).

For each site in each year numbers of lineata and redimita in the first sample were compared between males (mature and immature) and immature females using $2 \times 2$ contingency chisquared or Fisher's exact tests. In all cases they were homogeneous. To test whether morph frequency differences between the sexes exist but are not revealed because of small sample sizes, Cochran's Y statistic (Everitt, 1977) was calculated using all 27 comparisons in which at least one redimita was scored in the early sample. The value of $\mathrm{Y}$ was found to be 1.76 , with an associated probability of 0.078 . Thus, although there is a tendency for redimita frequency to be higher in immature females than in males, this trend is not significant.

Total numbers of lineata and redimita (males plus immature females) from the first sample were compared with those from the second sample using the same method as above. This comparison tests the null hypothesis that the frequency of late developing redimita is zero. The difference in redimita frequency between the second and the first samples will estimate the frequency of the late developing pattern.

Confidence limits were placed on the frequency of early developing redimita by transforming the estimated frequency to angles $\left(\sin ^{-1} \sqrt{p}\right)$, setting 95 per cent confidence intervals $( \pm 1.96 \sqrt{821 / N}$, where $N=$ sample size) and then back transforming. Sampling was with replacement in all but three cases, so there will be zero covariance between the first and second estimates of redimita frequency. Confidence limits for the difference between redimita frequencies in the two samples were therefore based simply on the summation of the variances for each sample, calculated as described above. Finally, the ratio of early developing to total redimita was calculated as the quotient of redimita frequencies in the first and in the second samples. The standard error of this ratio is estimated by

$$
\sqrt{\frac{\operatorname{Var} p_{1}}{p_{2}^{2}}+\frac{p_{1}^{2} \operatorname{Var} p_{2}}{p_{2}^{4}}}
$$

where $p_{1}$ and $p_{2}$ are the observed frequencies and Var $p_{1}$ and Var $p_{2}$ are the appropriate binomial variances, $p(1-p) / N$, in the first and second samples, respectively (Kendal and Stuart, 1969 p. 232). The additional term mentioned in Kendal and Stuart (1969) can be ignored because the covariance between samples is zero. Confidence intervals for this ratio cannot be easily calculated since they will be asymmetric to an unknown extent.

The data on which this study is based are given in table 2 and estimates of the frequency of early and late developing redimita, and of the ratio of early redimita to total, in table 3 . The geographical pattern in the value of this ratio is shown in fig. 1 . Ratios for all sites are included, irrespective of whether or not they are based on data showing significant differences between first and second samples. This has been done because the twosample method employed is insensitive to low frequencies of late developing redimita.

\section{DISCUSSION}

Estimates of phenotype frequencies at the regulatory locus controlling the timing of red pigment deposition in redimita were made using a twosample technique. Although this maintains natural densities of spiders and is quick, the large sampling errors mean that low frequencies of the late developing pattern will not be detected in statistical tests. It would be more efficient to collect spiders early in the season and to rear individual females in the laboratory. However, this requires more effort and perturbs population densities.

Ratios of early developing to total redimita were calculated without respect to whether successive samples differed in their proportions of lineata and redimita. If there really are no late developing redimita at a site, then differences in this morph's frequency between first and second samples would result from sampling errors, and should show no systematic bias. However, in pairs of samples taken at sites $B, E, G, K, N$ and $Z, 11$ of the 13 comparisons have higher redimita frequencies in the second sample (binomial test, $P=0.023$ ), suggesting that some of these colonies 
Table 2 Numbers and sex of each visible morph in each collection

\begin{tabular}{|c|c|c|c|c|c|c|c|}
\hline \multirow[b]{2}{*}{ Site } & \multirow[b]{2}{*}{ Year } & \multirow[b]{2}{*}{ Sex } & \multicolumn{3}{|c|}{ Morph } & \multirow[b]{2}{*}{ Total } & \multirow[b]{2}{*}{$\mathrm{P} \dagger$} \\
\hline & & & lineata & redimita & ovata & & \\
\hline \multirow[t]{3}{*}{ A } & \multirow[t]{3}{*}{82} & male & 76 & 4 & 0 & 80 & \\
\hline & & female I* & 98 & 4 & 0 & 102 & $P<0.001$ \\
\hline & & female $\mathrm{M}^{*}$ & 371 & 60 & 0 & 431 & \\
\hline \multirow[t]{12}{*}{ B } & \multirow[t]{3}{*}{80} & male & 14 & 1 & 0 & 15 & \\
\hline & & female I & 19 & 2 & 3 & 24 & N.S. \\
\hline & & female $\mathrm{M}$ & 183 & 11 & 28 & 222 & \\
\hline & \multirow[t]{3}{*}{81} & male & 19 & 0 & 2 & 21 & \\
\hline & & female I & 23 & 3 & 3 & 29 & N.S. \\
\hline & & female $\mathrm{M}$ & 238 & 23 & 22 & 283 & \\
\hline & \multirow[t]{3}{*}{83} & male & 48 & 1 & 3 & 52 & \\
\hline & & female I & 14 & 0 & 1 & 15 & N.S. \\
\hline & & female $\mathrm{M}$ & 669 & 49 & 71 & 789 & \\
\hline & \multirow[t]{3}{*}{84} & male & 52 & 2 & 8 & 62 & \\
\hline & & female I & 74 & 6 & 12 & 92 & N.S. \\
\hline & & female $\mathrm{M}$ & 442 & 31 & 31 & 484 & \\
\hline \multirow[t]{6}{*}{ D } & 82 & male & 62 & 2 & 0 & 64 & \\
\hline & & female I & 78 & 7 & 0 & 85 & $0.05>P>0.01$ \\
\hline & & female $\mathrm{M}$ & 101 & 18 & 0 & 119 & \\
\hline & 84 & male & 57 & 5 & 0 & 62 & \\
\hline & & female I & 60 & 3 & 0 & 63 & N.S. \\
\hline & & female $\mathrm{M}$ & 142 & 18 & 0 & 160 & \\
\hline $\mathrm{E}$ & 81 & male & 12 & 2 & 4 & 18 & \\
\hline & & female I & 14 & 2 & 4 & 20 & N.S. \\
\hline & & female $M$ & 110 & 24 & 17 & 145 & \\
\hline & 84 & male & 49 & 5 & 1 & 55 & \\
\hline & & female I & 95 & 22 & 1 & 118 & N.S. \\
\hline & & female $\mathrm{M}$ & 213 & 47 & 10 & 270 & \\
\hline G & 82 & male & 37 & 5 & 1 & 43 & \\
\hline & & female I & 76 & 11 & 1 & 88 & N.S. \\
\hline & & female $M$ & 182 & 30 & 5 & 217 & \\
\hline & 84 & male & 35 & 1 & 0 & 36 & \\
\hline & & female I & 32 & 4 & 0 & 36 & N.S. \\
\hline & & female $\mathrm{M}$ & 49 & 7 & 1 & 57 & \\
\hline I & 83 & male & 20 & 4 & 1 & 25 & \\
\hline & & female I & 58 & 9 & 5 & 72 & $\mathrm{P}=0.01$ \\
\hline & & female $M$ & 272 & 102 & 26 & 400 & \\
\hline $\mathrm{Ja}$ & 80 & male & 27 & 0 & 0 & 27 & \\
\hline & & female I & 41 & 0 & 0 & 41 & $\mathrm{P} \ll 0.001$ \\
\hline & & female $\mathrm{M}$ & 105 & 54 & 0 & 159 & \\
\hline $\mathrm{Jb}$ & $76 \neq$ & male & 17 & 0 & 0 & 17 & \\
\hline & & female I & 27 & 0 & 0 & 27 & $P \ll 0.001$ \\
\hline & & female $\mathbf{M}$ & 370 & 167 & 0 & 537 & \\
\hline & $81 \neq$ & male & 34 & 1 & 0 & 35 & \\
\hline & & female I & 40 & 1 & 0 & 41 & $P \ll 0.001$ \\
\hline & & female $\mathrm{M}$ & 296 & 141 & 0 & 437 & \\
\hline & 84 & male & 36 & 0 & 0 & 36 & \\
\hline & & female I & 60 & 0 & 0 & 60 & $\mathrm{P} \ll 0.001$ \\
\hline & & female $\mathrm{M}$ & 122 & 59 & 3 & 184 & \\
\hline K & $81 \neq$ & male & 30 & 3 & 2 & 35 & \\
\hline & & female I & 43 & 9 & 3 & 55 & N.S. \\
\hline & & female $\mathbf{M}$ & 260 & 62 & 7 & 329 & \\
\hline & 84 & male & 38 & 10 & 0 & 48 & \\
\hline & & female I & 44 & 4 & 2 & 50 & N.S. \\
\hline & & female $M$ & 115 & 28 & 2 & 145 & \\
\hline $\mathbf{N}$ & 82 & male & 62 & 9 & 0 & 71 & \\
\hline & & female I & 106 & 14 & 0 & 120 & N.S. \\
\hline & & female $\mathrm{M}$ & 628 & 86 & 0 & 714 & \\
\hline $\mathrm{O}$ & 84 & male & 50 & 2 & 1 & 53 & \\
\hline & & female I & 88 & 4 & 1 & 93 & $P<0.001$ \\
\hline & & female $M$ & 129 & 34 & 4 & 167 & \\
\hline
\end{tabular}


Table 2 (continued)

\begin{tabular}{|c|c|c|c|c|c|c|c|}
\hline \multirow[b]{2}{*}{ Site } & \multirow[b]{2}{*}{ Year } & \multirow[b]{2}{*}{ Sex } & \multicolumn{3}{|c|}{ Morph } & \multirow[b]{2}{*}{ Total } & \multirow[b]{2}{*}{$\mathrm{P}+$} \\
\hline & & & lineata & redimita & ovata & & \\
\hline \multirow[t]{6}{*}{ Q } & \multirow[t]{3}{*}{81} & male & 27 & 9 & 2 & 38 & \\
\hline & & female I & 29 & 4 & 0 & 33 & N.S. \\
\hline & & female $\mathrm{M}$ & 77 & 23 & 0 & 100 & \\
\hline & \multirow[t]{3}{*}{84} & male & 36 & 3 & 3 & 42 & \\
\hline & & female I & 62 & 13 & 1 & 76 & $0.01>P>0.001$ \\
\hline & & female $\mathrm{M}$ & 240 & 84 & 8 & 332 & \\
\hline \multirow[t]{6}{*}{$\mathrm{U}$} & \multirow[t]{3}{*}{81} & male & 19 & 0 & 2 & 21 & \\
\hline & & female I & 53 & 2 & 1 & 56 & $P \ll 0.001$ \\
\hline & & female $M$ & 137 & 68 & 11 & 216 & \\
\hline & \multirow[t]{3}{*}{84} & male & 27 & 0 & 0 & 27 & \\
\hline & & female I & 66 & 2 & 3 & 71 & $\mathrm{P} \ll 0.001$ \\
\hline & & fermale $\mathrm{M}$ & 62 & 25 & 4 & 91 & \\
\hline \multirow[t]{6}{*}{$\mathbf{Z}$} & \multirow[t]{3}{*}{81} & male & 14 & 2 & 0 & 16 & \\
\hline & & female I & 17 & 10 & 0 & 27 & N.S. \\
\hline & & female $\mathrm{M}$ & 46 & 21 & 0 & 67 & \\
\hline & \multirow[t]{3}{*}{84} & male & 6 & 4 & 0 & 10 & \\
\hline & & female I & 13 & 6 & 0 & 19 & N.S. \\
\hline & & female $\mathrm{M}$ & 20 & 14 & 0 & 34 & \\
\hline \multirow[t]{3}{*}{$\mathrm{AB}$} & \multirow[t]{3}{*}{83} & male & 46 & 0 & 0 & 46 & \\
\hline & & female $\mathrm{I}$ & 69 & 1 & 0 & 70 & $0.01>\mathrm{P}>0.001$ \\
\hline & & female $\mathrm{M}$ & 299 & 30 & 0 & 329 & \\
\hline \multirow[t]{3}{*}{$\mathrm{AC}$} & \multirow[t]{3}{*}{82} & male & 86 & 0 & 0 & 86 & \\
\hline & & female I & 89 & 0 & 3 & 92 & $P \ll 0.001$ \\
\hline & & female $\mathrm{M}$ & 420 & 119 & 17 & 556 & \\
\hline \multirow[t]{6}{*}{$\mathrm{AD}$} & \multirow[t]{3}{*}{81} & male & 43 & 3 & 0 & 46 & \\
\hline & & female I & 62 & 4 & 0 & 66 & $0.01>P>0.001$ \\
\hline & & female $\mathrm{M}$ & 119 & 31 & 0 & 150 & \\
\hline & \multirow[t]{3}{*}{84} & male & 70 & 3 & 0 & 73 & \\
\hline & & female I & 83 & 10 & 0 & 93 & $0.01>P>0.001$ \\
\hline & & female $\mathrm{M}$ & 241 & 54 & 2 & 297 & \\
\hline \multirow[t]{3}{*}{$\mathrm{AF}$} & \multirow[t]{3}{*}{84} & male & 38 & 0 & 0 & 38 & \\
\hline & & female I & 86 & 1 & 0 & 87 & $P \ll 0.001$ \\
\hline & & female $\mathrm{M}$ & 261 & 69 & 0 & 330 & \\
\hline \multirow[t]{3}{*}{$\mathrm{AO}$} & \multirow[t]{3}{*}{83} & male & 22 & 0 & 0 & 22 & \\
\hline & & female I & 84 & 0 & 0 & 84 & $0.01>\mathrm{P}>0.001$ \\
\hline & & female $M$ & 249 & 23 & 0 & 272 & \\
\hline
\end{tabular}

* I = Immature, $M=$ Mature.

$\dagger$ Probability associated with a $2 \times 2$ chi-squared test for differences in numbers of lineata and redimita between female ${ }_{1}+$ male and female $M$

$\ddagger$ First samples collected from the field and reared in the laboratory. Changes in females on reaching maturity are as follows (lineata/redimita): Jb ('76) $27 / 0$ to $21 / 6$; Jb ('81) $40 / 1$ to $26 / 15 ; \mathrm{K}$ ('81) $43 / 9$ to $42 / 10$.

might have low frequencies of late developing redimita. Indeed, there is direct evidence for this at site $\mathrm{K}$. In a small sample of immature individuals returned to the laboratory for breeding purposes one lineata female changed to redimita on reaching maturity (see footnote to table 2).

Two main regions are defined by the distribution of regulatory phenotypes (fig. 1). The south/central area (sites G, B, E, Q, Z and K) has a high frequency of the early developing phenotype which decreases to the north and south. This phenotype is essentially absent from the region above site AD. The low frequencies in $\mathrm{U}$ and $\mathrm{Jb}$ almost certainly result from an experimental introduction from a site between $\mathrm{B}$ and $\mathrm{E}$ (Oxford and Shaw, in preparation).

One anomaly is the isolated site $\mathrm{N}$ in the extreme north of the area, where all redimita apparently develop early. In 1975 a small sample $(\mathrm{N}=50)$ revealed only lineata but one year (one generation) later, one redimita was found in a sample of 93 individuals. Since that time, the frequency of redimita has increased and in 1984 had reached a value of $0 \cdot 134$. The large mean population size at this site, estimated from the number of mature females sampled, means that the increase can only be ascribed to migration or selection (Oxford and Shaw, in prep.). The lower 
Table 3 Summary statistics of phenotype frequencies at the regulatory locus

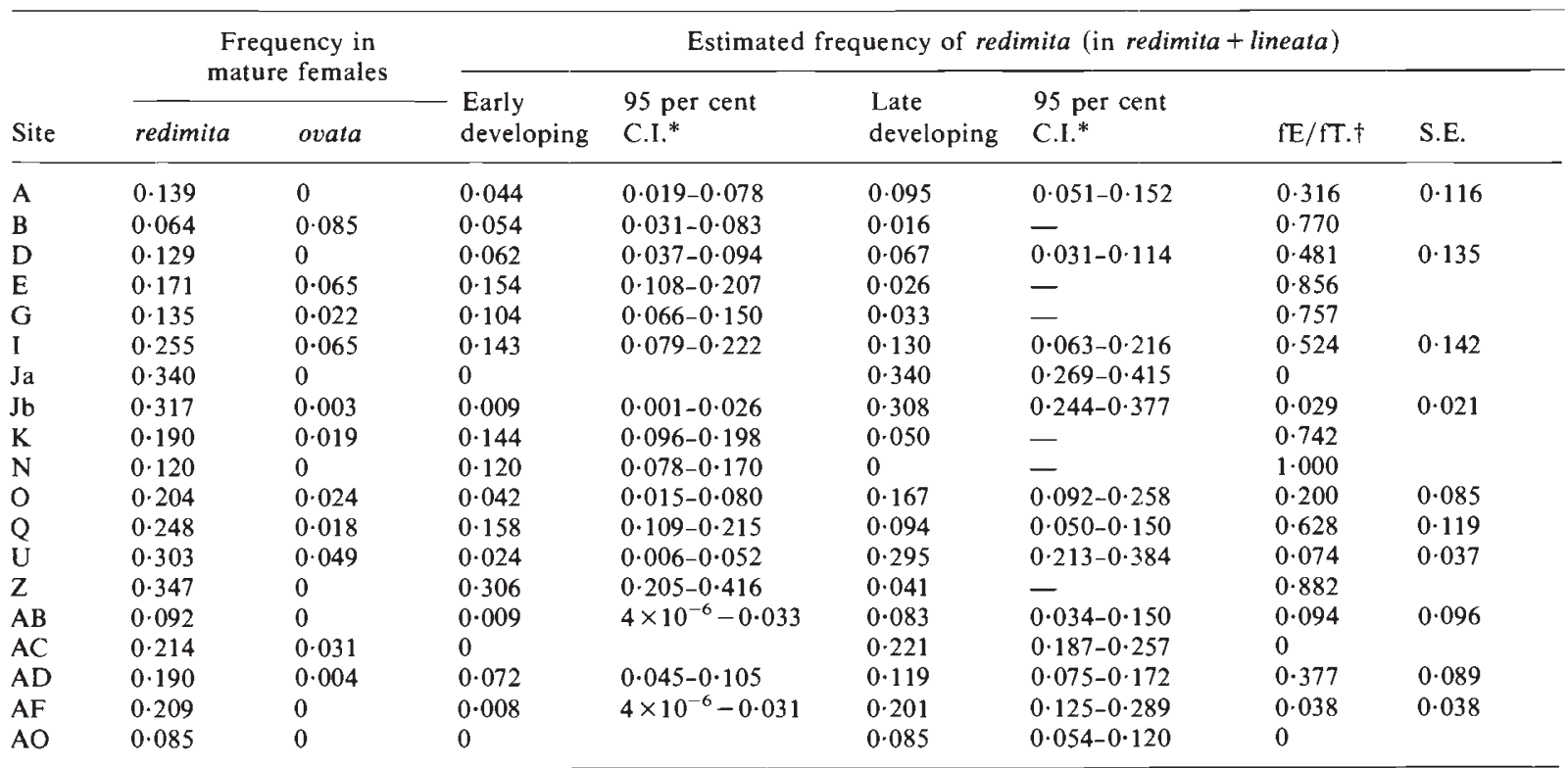

* 95 per cent confidence interval. A-in column 7 indicates the null hypothesis, that the frequency of late developing redimita is zero, was not rejected. $+\mathrm{fE}$ and $\mathrm{fT}$ refer to the frequencies of early developing and total redimita respectively.

overall frequency of redimita in the nearest colonies to $\mathrm{N}, \mathrm{AB}$ and $\mathrm{AO}$, and the striking differences at the regulatory locus reduces the probability that migration is an explanation.

In populations fixed for one or the other allele, the regulatory locus determines when the population becomes visibly polymorphic (given that the frequency of ovata is low in virtually all sites nearly fixed for the late allele). In 1980 sites B and Ja were sampled at two week intervals from May 21 st onwards. Carapace widths of all individuals were measured and approximate instars assigned with the tables in Seligy (1971). Most spiders were in their third instar on May 21st and the majority were fourth instar on June 4th. By June 4th, the proportions of morphs at site B were statistically indistinguishable from those in the sample of mature females scored in August. At Ja all spiders were lineata although carapace size distributions were identical to those at B on this and all other sampling dates. Not until July 1st was the first redimita found at Ja and by July 18 th 29.7 per cent of females were of this morph.

Thus, populations in sites $\mathrm{B}$ and $\mathrm{Ja}$ differ by between four and six weeks in developing a visible polymorphism. As soon as females are mature they mate and one to two weeks later have established themselves in rolled leaves prior to egg laying. At late developing sites, therefore, the spider population is visibly polymorphic and exposed to selective factors e.g. predators or solar radiation, for only two weeks, so that if visible, rather than pleiotropic, effects of the structural alleles are of importance, selection must act swiftly. As yet there is no direct evidence for selection on the visible morphs.

Although the areas of approximately uniform phenotype frequencies at the regulatory locus are small in terms of absolute distances, they are large compared to the between-site variability found for the visible morphs (Oxford, 1976; Oxford and Shaw, in prep.). The extreme differentiation at these two loci might result from bottlenecks in the past. In the late 1940's the main roads through the area were widened and resurfaced and many of the existing verges were disturbed by excavation (B. Gill, personal communication). If small isolated populations of spiders survived, then stochastic events, both at and immediately after their formation, may have perturbed allele frequencies at both loci. The present situation might represent a stage in the gradual return to a global equilibrium for the area, mediated by migration and/or selection (Oxford and Shaw, in prep.). None of the correlations between the ratio of early developing to total redimita and the frequencies in mature females of lineata, redimita and ovata (table 3 ) are significant, and there are no obvious associations between this ratio and altitude, aspect or vegetation (table 1). Observed changes at site $\mathrm{N}$ since 1975 suggest that selection, either on the 
structural locus itself or on closely linked loci, does play a role in determining morph frequencies.

As far as I am aware only one other published study has compared the distribution of genetic variation at associated regulatory and structural loci within a species. Powell (1979) investigated three polymorphisms affecting the amylase ( $A m y)$ locus in Drosophila pseudoobscura. He found coordinated variation of electrophoretically distinct alleles at the $A m y$ locus and chromosome 3 inversions but no association between these and patterns of expression of Amy in the midgut, controlled by regulatory elements (Powell and Lichtenfels, 1979). An independence of midgut patterns and electrophoretic variation is also found in comparisons of seven other Drosophila species (Powell et al., 1980). A similar lack of correlation exists between variation at regulatory and structural loci in Enoplognatha.

Heller and Volokita (1981) found that geographical differences in the timing of black pigment deposition in the shell of Xeropicta vestalis in Israel were of adaptive significance. Shell pigmentation is important in the thermal adjustment of the snail and the initiation and cessation of pigment formation was found to be appropriate to the contrasting climates of mountain and coastal plain. Powell and Andjelković (1983) and Powell and Amanto (1984) found directional changes in the frequencies of midgut amylase patterns in Drosophila pseudoobscura under stress conditions. In populations living on medium containing starch as the only carbohydrate source, one midgut pattern increased in frequency. No such increase was observed in control cages with medium containing maltose as the sole carbohydrate source. Powell and co-workers argue that these changes are best interpreted as the result of selection acting on the regulatory loci controlling midgut patterns. As yet, no adaptive function can be ascribed to geographical variation at the regulatory locus in Enoplognatha, although one cannot discount the possibility that one exists.

Acknowledgements 1 would like to thank Terry Crawford and Michael Shaw for commenting on drafts of this paper, and John Byrne, Terry Crawford, Peter O'Donald and Mark Williamson for discussion. Richard Pitts assisted with the field work. Mr B. Gill, County Divisional Surveyor for North Yorkshire County Council, kindly supplied information about past road reconstruction in the Nidderdale study area. Some of the work reported here was supported by a Science Research Council grant (GR/A55417).

\section{REFERENCES}

ABRAHAM, I. AND DOANE, W. W. 1978. Genetic regulation of tissue-specific expression of amylase structural genes in Drosophila melanogaster. Proc. Natl. Acad. Sci. U.S.A., 75, 4446-4450.

ALLENDORF, F. W., KNUDSEN, K. L. AND PHELPS, S. R. 1982. Identification of a gene regulating the tissue expression of a phosphoglucomutase locus in rainbow trout. Genetics, 102, 259-268.

BARNES, B. W. AND BIRLEY, A. J. 1978. Genetic variation for enzyme activity in a population of $D$. melanogaster IV. Analysis of alcohol dehydrogenase activity in chromosome substituted lines. Heredity, 40, 51-57.

DICKINSON, W. J. 1975. A genetic locus affecting the developmental expression of an enzyme in Drosophila melanogaster. Develop. Biol., 42, 131-140.

DICKINSON, w. J. 1981. Evolution of patterns of gene expression in Hawaiian picture-winged Drosophila. J. Mol. Evol., 16, 73-94.

EVI:RI1T, B. S. 1977. The Analysis of Contingency Tables. Chap. man and Hall, London.

Gould, S. J. 1977. Ontogeny and Phylogeny. Harvard University Press, Cambridge, Massachusetts.

HEDRICK, P. W. AND MCDONALI), J. F. 1980. Regulatory gene adaptation: An evolutionary model. Heredity, 45, 83-97.

HELLER, J. AND VOLOKITA, M. 1981. Gene regulation of shell banding in a land snail from Israel. Biol. J. Linn. Soc., 16, 261-277.

HOORN, A. AND SCHARLOO, W. 1981. The functional significance of amylase polymorphism in Drosophila melanogaster VI. Duration of development and amylase activity in larvae when starch is a limiting factor. Genetica, 55, 195-202.

KENDAL, M. G. AND STUART, A. 1969. The Advanced Theory of Statistics Vol. $13 \mathrm{rd}$ Ed. Griffin and Co. London.

LAURIE-AHLBERG, C. C., WILTON, A. N., CURTSINGER, J. W. AND EMIGH, T. H. 1982. Naturally occurring enzyme activity variation in Drosophila melanogaster I. Sources of variation for 23 enzymes. Genetics, 102, 191-206.

McDONALD, J. F. 1983. The molecular basis of adaptation: A critical review of relevant ideas and observations. Ann. Rev. Ecol. Syst., 14, 77-102.

MCDONALD, J. F., CHAMBERS, G. K., IDAVID, J. AND AYALA, F. J. 1977. Adaptive response due to changes in gene regulation: A study with Drosophila. Proc. Natl. Acad. Sci. USA, 74, 4562-4566.

MARON1, G. AND LAURIE-AHLBERG. C. C. 1983. Genetic control of $\mathrm{ADH}$ expression in Drosophila melanogaster. Genetics, 105, 921-933.

OXFORD, G. S. 1976. The colour polymorphism in Enoplognatha ovatum (Clerck) (Araneae: Theridiidae)-Temporal stability and spatial variability. Heredity, 36, 369-381.

OXFORD, G.S. 1983. Genetics of colour and its regulation during development in the spider Enoplognatha ovata (Clerck) (Araneae: Theridiidae). Heredity, 51, 621-634.

PAIGFN, K. 1979. Genetic factors in developmental regulation. In J. G. Scandalios (ed.), Physiological Genetics, pp. 1-61. Academic Press, London.

POWELL, J, R. 1979. Population genetics of Drosophila amylases II. Geographic patterns in D. pseudoobscura. Genetics, 92, 613-622.

POWEll, J. R. AND LiChtFNFEls, J. M. 1979. Population genetics of Drosophila a mylases I. Genetic control of tissuespecific expression in D. pseudoobscura. Genetics, 92, 603612. 
POWEll, J. R. AND AMANTO, G. D. 1984. Population genetics of Drosophila amylases V. Genetic background and selection on different carbohydrates. Genetics, 106, 625-629.

POWELl, J. R. AND ANDJELkOVIĆ, M. 1983. Population genetics of Drosophila amylases IV. Selection in laboratory populations maintained on different carbohydrates. Genetics, 103, 675-689.

POWELL, J. R., RICO, M. AND ANDJELKović, M. 1980. Population genetics of Drosophila amylases III. Interspecific variation. Evolution, 34, 209-213.

SCHWARTZ, D. 1962. Genetic studies on mutant enzymes in maize III. Control of gene action in the synthesis of $p \mathrm{H}$ $7 \cdot 5$ esterase. Genetics, 47, 1609-1615.
SELIGY, V. L. 1971. Postembryonic development of the spider Enoplognatha ovata (Clerck) (Araneae: Theridiidae). Zool. J. Linn. Soc., 50, 21-31.

TEJIMA, T. AND OHBA, S. 1981. Genetic regulation of amylase activity in Drosophila virilis I. Activity variation among laboratory strains. Jpn. J. Genet., 56, 457-468.

WILSON, A. C. 1976. Gene regulation in evolution. In F. J. Ayala (ed.) Molecular Evolution pp. 225-234. Sinauer Assoc. Inc. Sunderland, Massachusetts.

WILSON, P. AND MCDONALD, J. F. 1981. A comparative study of enzyme activity variation between $\alpha$-glycerophosphate and alcohol dehydrogenases in D. melanogaster. Genetica, $55,75-79$. 